\title{
THE LEGAL CONTENT OF THE PROFIT CONCEPT
}

\author{
COLIN A. COOKE $\dagger$
}

IT HAS been said that "law and economics are ever and everywhere complementary and mutually determinative, like form and content." 1 This idea was more general in the eighteenth century, when a composite social theory was the object of writers on philosophy and law. So we find discussions of the function of money in the works of such juristic writers as Pufendorf, Grotius, and Montesquieu, a compound theory of political economy and jurisprudence in Adam Smith, and a derivation of justice in Hume's philosophy from the same scarcity of means and ends which is the fundamental postulate of modern economics." But since then the social studies have become extensively departmentalized and, while it is easy to see that the economics of society and the law of society cover the same social material, it is much more difficult to find any connection between economic and legal theory.

The two studies proceed from different sets of postulates, and the divergences of their theories are in part due to this. But there is also a difference of method between the two which has had important consequences in influencing the trend towards their separation. The economist proceeds by analysis of the concepts of his science, tentative hypotheses whose utility is tested by a statistical examination of the conclusions deduced from them. ${ }^{3}$ In law there has been a similar analysis of juristic concepts, but the realistic studies comprise the practical examination and decision of cases. Since every case concerns a particular dispute over a particular issue between individuals, the decision depends on whether the set of facts comes within one legal category or another. The cumulative effect of the flow of cases is to establish the limits of these categories. The contrast with the economic method is then that a legal concept is definable only by reference to the limits established by case law, but. an economic conception is definable at the will of each economist (perhaps it should be added, with the concurrence of his fellows). To take an example: the law of contract contains the concepts of offer and acceptance and the content of these can be determined only by an examination of the limiting cases decided in the courts. . But an economic concept such as rent or price is defined abstractly, its definition varying from economist to economist even where there is a substantial measure

$\div$ Fellow of University College, Oxford.

1. Berolzhetarer, The World's Legal Philosophies (1912) 22, 23.

2. Cooke, Adam Snith and Jurisprudence (1935) 51 L. Q. Rev. 326.

3. Pigou, The Function of Economic Analysis, in Prgou and Ropentson, Econonic Essays and Addresses (1931); of. Robins, The Nature and Significance of Econoartc ScIEnce (1932). 
of common agreement; there is no limitation from the particulars of real instances.

One English economist of the nineteenth century suggested that law, in its bearings on the operation of the economic function in society, is a subject demanding the economist's investigation." And some attempts have been made to incorporate the legal principles on which the economic system works in an economic theory of that system. ${ }^{5}$ But it is not unfair to say that the link between economics and law is generally conceived by economists to be the relation between a mechanism and its direction; law is the operative mechanism by which economic policy works. Its most extreme form is exemplified by the Marxist theory of law as the medium of control used by the dominant class. And although statutes may express the economic policies of dominant classes, nevertheless the application of these statutes is subject, at least in the United States and Britain, to legal theory rooted in the continuity of the social system. Law is certainly a mechanism, a mechanism for the settlement of disputes and a mechanism of social control, but it derives more directive force from legal doctrine than from any other source. It follows that economic criticism of law must, to be valid, take these doctrines into account, and that a criticism based on economic analysis from economic postulates can have no direct relevance to the legal problem save by way of helping to define the objectives which the legal solution should approximate if it can.

This is not to say that the law contains all the economic doctrine it needs. It does not, as, for instance, the cases on restraint of trade show. But it does mean that the economic content of legal doctrine can only be increased by the assimilation of economic principles drawn from postulates common to both economics and law. In these days of specialization this is much easier said than done. Yet it does not involve the abandonment of existing economic theory and the immensely valuable contributions it has made to social thought and social progress. The combination of economics with law is more likely to come from the exploration of case law by economists, because the concrete problems of particular sets of facts are all that is really needed to bring about an approximation of legal and economic definition. Both law and economics would benefit by such explorations. The few economic studies of conceptions common to law and economics indicate to what an extent the economic ideas used in law are inconsistent and even incoherent. And there are unrealistic ideas in many fields of economic thought which the

4. Lestie, Essays in Political and dioral Philosophy (1879) 404.

5. Notably in Conrarons, Legal Foundations of Capiralisar (1924).

6. See Robson, Legal Conceptions of Capital and Inconse, Loindon Essays int Econosics (1928) 251; Cooke, Legal Rule and Economic Function (1936) 46 Econ. J. 21. 
concrete problems of case law might break down into forms perhaps less general but much closer to experience, and more uniformly described. One of the difficulties which meets a court endeavoring to discover the content of an economic concept for legal purposes is the conflict of views among economists. ${ }^{7}$

This difficulty of definitions is conspicuous in the economic and legal thought on profit, a conception, it need hardly be added, which lies at the basis of the economic structure of England and America. But in spite of the fact that in most modern communities economic enterprise is in part at least the function of private profit derived from private property, there is disagreement among economists on the nature and analysis of profit and there is corresponding difficulty in the courts in interpreting the word. It is not proposed in the present article to attempt any discussion of the various economic theories of profit. $^{8}$ Its aim is an examination of some part of the extensive case law dealing with profits in order that some economic assessment of the content of profit as a practical legal conception may be attempted.

An English judge once complained ${ }^{0}$ that he could find no simple definition of profit that would fit all cases, though he leaned towards a definition given in Marshall's Principles of Econonics. This definition runs as follows: "When a man is engaged in business, his profits for the year are the excess of his receipts from his business during the year over his outlay for his business; the difference between the value of his stock and plant at the end and at the beginning of the year being taken as part of his receipts or as part of his outlay, according as there has been an increase or decrease of value." 10 In other words the business has a certain value at the beginning of the year. At the end of the year there have been increases and decreases in the items making up this value, and the difference between the old value and the new represents the profit (or loss) of the business for the year. From another point of view the purpose of a business is to generate an income for its owners, who have contributed the fund necessary for its operation. Assuming no further contributions to this fund by the owners, the annual profit is the increase in this fund produced by the operation of the business in each year. It is the analysis of this increase that the courts have found difficult. Distinctions between capital, gross income and net in-

7. See Parry, Econonic Theories in English Case Law (1931) 47 L. Q. REv. 183, and cases there cited at 191, 192.

8. The literature is so extensive that it may be useful to cite three discussions of a number of economic theories of profit: KNIGET, Risk, UnCERTaINTY and Profrt (1920) c. II and IX; CanNan, A Review of Econonic Theory (1929) c. X, §4; Dobb, Capitalist Enterprise and Soctal Progress (1925) c. V and VI.

9. Bond v. Barrow Haematite Steel Co., [1902] 1 Ch. 353, 366.

10. (1st ed. 1890) 142. A similar but not identical wording is in the 8th edition at p. 74. 
come have arisen, and it is significant that the judge who cited Marshall's definition of profit with approval found himself unable to use it in law because he was encumbered with cases in which much had been made of the difference between fixed and circulating capital.

There are two series of cases in which profits, capital, and income have been debated. The first arises under the statutes relating to joint stock companies, and the second under the Income Tax Acts. The two main problems which these cases consider are what constitutes profit for the purposes of paying dividends and what constitutes profit for purposes of taxation. There is some overlapping of the doctrines derived from the resolving of these two problems, but it is convenient to deal with the evolution of each separately, although reference to the other will be occasionally necessary.

Taking company dividends first, it is familiar doctrine that dividends can be paid onily out of profits, ${ }^{11}$ but there is no clear definition of what constitutes profits in company legislation. There was appended to the Companies Act, 1862,12 a schedule of regulations for the management of companies which provided that the directors should lay before the company at least once a year a statement of the income and expenditure for the past year. "The statement so made shall show, under the most convenient heads, the amount of gross income, distinguishing the several sources from which it has been derived, and the amount of gross expenditure, distinguishing the expense of the establishment, salaries and other like matters. Every item of expenditure fairly chargeable against the year's income shall be brought into account, so that a just balance of profit and loss may be laid before the meeting." 13 The conclusion that profit is thus gross income, less the expenditure chargeable against the year's income, requires the elucidation of what constitutes gross income and what is expenditure chargeable against it. These two problems fall naturally into the two avenues of interpretation: income into company law, where division of the income is the source of litigation, and expenditure chargeable against income into income tax law, where the litigant is concerned about the size of an assessed income.

It has been held that where a company has sold part of its capital assets at a profit, with the result that the total value of these assets exceeds its paid-up capital, the excess may be treated as part of the company's gross income and carried to profit and loss account. ${ }^{14}$ Again,

11. See 25 \& 26 Vict. c. 89, Table A, Clause 73 (1862); Evans v. Coventry, 25 L. J. Ch. 489 (1856) ; Rance's Case, L. R. 6 Ch. App. 104 (1S70); Guinness v. Land Corp. of Ireland, 22 Ch. D. 349 (ISS2).

12. 25 \& 26 Vict. c. S9, Table A (1862).

13. 25 \& 26 Vict. c. 89,1 st Schedule, Clause 80 (1S62).

14. Iubbock v. British Bank of South America, [1S92] 2 Ch. 19s; Foster v. New Trinidad Lake Asphalt Co., [1901] $1 \mathrm{Ch}$. 208. See also In re National Bank of Wales, Itd., [1599] 2 Ch. 629. 
it was held as far back as 1869 that where a company estimates that it has made a profit it need not actually wait to realize all its assets to ascertain whether a profit has actually been made, but may pay a dividend on the basis of its estimation. ${ }^{15}$ Hence if a company estimates that its capital assets have increased in value during a year the increase may be treated as a contribution to gross income, although there is some doubt as to whether dividends may be paid from this source alone. ${ }^{10}$ The rule of practice seems to be that if the capital remains in the balance sheet at levels of previous years and the profit and loss account shows a profit, including these sources of gross income, then that is a true profit for dividend purposes. ${ }^{17}$ This echoes the simple statement in an early case, that profit "is the amount got from the property minus the cost of getting it."18 A difficult problem, however, may be found in the question whether, when there has been a fall in the capital assets of a company, this fall is part of the cost of getting profit. Has a company to meet losses of capital, or depreciation, of its assets before it can arrive at a true profit?

The first answer in English law was that, as a dividend could be paid only out of profits and could not be paid out of capital, the capital must be at its established level before profits for dividend purposes appeared. In Davison v. Gillies $^{10}$ a company was restrained from paying a dividend because its stock was depreciated, in spite of the existence of a surplus on profit and loss account. And in Dent v. London Tranizvays it was said that dividends were payable from the "profits for the year," which meant the surplus of receipts after paying expenses and restoring the capital to its level at the beginning of the year. ${ }^{20}$ Hence the accounting period must be regarded as closed at both ends. There may be a loss on the balance sheet and a consequent fall in capital assets in one period, but if there are profits in a later year it is the position of the capital assets on the first day of that later year that is considered. The previous fall is of no legal account and does not diminish later profits.

Some years later it was decided in the Court of Appeal that where a company was formed to work a wasting asset, such as a mine, and its articles of association stated that it was not necessary to provide for the depreciation of the mine, there was nothing in the Companies

15. Stringer's Case, L. R. 4 Ch. App. 475 (1869).

16. In re Spanish Prospecting Co., Itd., [1911] 1 Ch. 92; Ammonia Soda Co. v. Chamberlain, [1918] 1 Ch. 266. Contra: Wall v. London and Brovincial Trust, Ltd, [1920] 1 Ch. 45.

17. See Gore-Brown, Handbook on Joint Stock Conrpanies (38th ed.) 476; de Paula, Princtrles of Auditing (8th ed.) 190.

18. Jessel, M. R., in Erichsen v. Last, 51 Q. B. D. 86 (1881).

19. 16 Ch. D. 347 (1879).

20. 16 Ch. D. 344,354 (1880). 
Acts to compel it to do so. ${ }^{21}$ Hence the Companies Acts were held not to compel the replacement of lost capital before arriving at profit; subsequently this decision was reiterated, ${ }^{22}$ but qualified in the important case of Verner $v$. General and Commercial Investment Trust. ${ }^{23}$ Here a company was formed to invest in securities and it was held that, in spite of the fact that its holdings had depreciated, the company could declare a dividend out of the surplus shown in its profit and loss account. Lindley, L. J., said that the legal rule is not that dividends can be paid only out of profits, but that they cannot be paid out of the shareholders' capital. They can, therefore, be paid out of a profit and loss account without providing for losses of capital on the previous balance sheet.

Thereafter, however, a distinction was developed between fixed and circulating or floating capital, a distinction which seems to have drifted into the law ${ }^{24}$ from the economic theory of the second half of the nineteenth century. ${ }^{25}$ The permanent (shareholders') capital lost in any year need not be made good in subsequent years before the declaration of a dividend. But where the capital used up in the business (such as stocks or raw materials) depreciated in the accounting year, this depreciation is a loss to set against gross profit. "Perhaps the shortest way of expressing the distinction is to say that fixed capital may be sunk and lost, and yet that the excess of current receipts over current payments may be divided, but that floating or circulating capital must be kept up, as otherwise it will enter into and form part of such excess, in which case to divide such excess without deducting the capital which forms part of it will be contrary to law." 20 On the basis of this distinction it was held in several later cases that dividends could be declared without providing for the depreciation of fixed assets. ${ }^{2 T}$

There was some amplification of the point in the National Bank of Wales case. ${ }^{28}$ The bank had paid certain dividends in spite of the fact that it was treating as good certain debts which it knew to be bad. Should this certain loss be set against gross profit or could it be treated as a loss of fixed assets in the balance sheet? It was held in the Court of Appeal'

21. Lee v. Neuchatel Asphalte Co., 41 Ch. D. 1 (18S9).

22. Bolton v. Natal Land and Colonization Co. [1S92] $2 \mathrm{Ch} .124$.

23. [1S94] 2 Ch. 239.

24. See Robson, London Essays in Economics (1928) 260.

25. See Mirll, Prnnciples of Political Econonsy (ed. Ashiey 1923) 91:

26. Lindley, L. J., in Verner v. General and Commercial Trust [1594] 2 Ch. 239, at 266.

27. Wilmer v. MicNamara \& Co., Ltd. [1S95] 2 Ch. 245; Ite re Kingston Cotton srill Co. [1896] 1 Ch. 331; Bosanquet v. St. John Dèl Rey Mrining Co., 77 L. T. 206

(Ch. D. 1897).

28. [1899] 2 Ch. 629. 
that the court will not interfere to prevent losses being charged to capital, except where they are obviously chargeable to profit and loss, the matter being one to be decided by business practice in the trade concerned. ${ }^{20}$ But when the case went to the House of Lords, ${ }^{30}$ the Law Lords did not expressly agree with the propositions of the Court of Appeal on fixed and circulating capital. The case was decided on a different point and the House was inclined, so far as it committed itself, to doubt whether a company, which has made a definite loss of fixed capital, may have a profit for dividend purposes until that loss has been provided for.

Although it is more than thirty years since the House of Lords thus reserved its decision on the relation of profit to capital losses, the occasion has not yet offered itself for a final statement of English law on the point. The Court of Appeal has continued to decide cases on the basis that a company can pay dividends on its profits even though it has lost part of its capital assets. ${ }^{31}$ And, indeed, it seemis that the profits of a particular year may be treated as profits for dividend purposes without first making good losses of previous years on the profit and loss account. ${ }^{32}$ The doctrine of fixed and circulating capital has also been carried even further, but as Scrutton, L. J., has said, all the distinction seems to mean at present is that dividends must be paid out of net and not out of gross profits. ${ }^{33}$

There is in the Income Tax Acts no guidance on the issue of what constitutes "profits". The amount to be assessed is "the balance of the profits or gains," and a series of provisions limit the deductions that may be made in arriving at this balance. A long series of cases has established the rule that the assessed balance must be computed by ordinary commercial principles, "by setting against the income earned the cost of earning it, subject to the limitations prescribed by the Act." 34 In general, the proper debit items in a trading or a profit and loss account are the only proper debit items in computing income tax. ${ }^{35}$ But an important exception is that determining the allowance for depreciation of plant; depreciation is a deduction from assessable profits, even though not a deduction made in the course of computing profits. Thus it has

29. Id. at 669,670 .

30. Dovey v. Cory, [1901] A. C. 477.

31. Bond v. Barrow Haematite Co., [1902] 1 Ch. 353; Ammonia Soda Co. v. Chamberlain, [1918] 1 Ch. 266.

32. Stapley v. Read Bros., 131 L. T. 629 (Ch. D. 1924).

33. Ammonia Soda Co. v. Chamberlain, [1918] 1 Ch. 266, at 298.

34. Lord Loreburn in Usher's Wiltshire Brewery, Ltd. v. Bruce, [1915] A. C. $433,444$.

35. A list of cases and authoritative statement of the law governing the computation of trading profits for income tax purposes is contained in the Report of the Income Tax Codification Committee, 1936, vol. 1, pp. 48-51. 
been held that the profits of a company whose capital was intact were merely its gross profits, for the purposes of taxation because no allowance had yet been made to meet depreciation of capital. ${ }^{36}$

This exception of depreciation is one of taxation procedure only, existing in order that the deduction of depreciation may be controlled. It is plain that the depreciation of plant is part of the cost of obtaining income from the plant, and, indeed, the fact has been recognized in law. It has been held that a person who is entitled under a deed to the profits of a business is entitled only to the profits after sums have been set aside for depreciation of machinery. ${ }^{37}$ True profit in the income tax classification is, therefore, not the assessable, but the taxable profit, that is to say, the assessable profit less the allowance for depreciation. But it is not safe to push these conceptions drawn from taxation law too far, because they vary in an important particular from the business aspect of profit. From the point of view of taxation the analysis of profit is the separation of the income generated by a capital fund from the fund itself. ${ }^{33}$ And until there is evidence that a company intends to convert its accumulated profits into capital, they remain profits and the capital constant. ${ }^{30}$ Such a conversion was held effected in Inland Reventue Commissioners $v$. Blott $t^{40}$ by the issuance of bonus shares, such shares coming to the stockholders as capital and not as income.

This legal separation of income from capital is common ground in English and American law. Thus the Law Lords forming the majority in Blott's case all referred with respect to the opinion of the Supreme Court of the United States in Eisner v. Macomber."11 In a later English case Sankey, J., carried further the analysis of Pitney, J., in Eisner $v$. Maconber. Here ${ }^{42}$ an English investment company received in respect of shares which it held in an American company an extra dividend out of the accumulated profits of that company consisting partly of cash and partly of common stock in another American company. The English company sold the stock, and the case concerned its liability to income tax on the proceeds of the sale; that is, had there been a distribution of

36. Davidson v. Commissioner of Taxes, [1917] A. C. (P. C.) 542.

37. Re Crabtree, 106 I. T. 49 (Ct. App. 1912).

3S. Cf. the cases concerning the interests of life tenants and remaindermen. See also Bouch v. Sproule, 12 App. Cas. 385 (1S87); Strachan, A Comsany's Capilal or Income (1930) 46 L. Q. REv. 334.

39. See Fry, I. J., in Sproule v. Bouch, 29 Ch. D. 635, at 655 (18s5): "Profits appear to us to retain their character of income till they are converted into capital." See also In re Bridgewater Navigation Co., [1S91] 2 Ch. 317; In re Spanish Prospecting Co., Itd., [1911] $1 \mathrm{Ch} .92$; and Irt re Thomas, [1916] $2 \mathrm{Ch} .331$.

40. [1921] 2 A. C. 171.

41. 252 U.S. 189 (1920). Seligman, Effects of the Sloct: Dizidend Decision (1921)

21 CoL. L. Rev. 313.

42. Pool v. Guardian Investment Trust Co., Itd. [1922]' 1 KC B. 347. 
capital or of income? Mr. Justice Sankey said that in his view the distinction depended on two points: (1) whether there had been a release of assets; (2) if so, whether the assets released were capital or income. From Eisner v. Macomber he drew the principle that mere growth or increment in value of a capital investment is not per se income; but that "income is essentially a gain or profit in itself of exchangeable value, proceeding from capital, severed from it and received by the taxpayer for his separate use, benefit and disposal." 43 A stock dividend in shares of the company making the dividend is merely a transfer of an accumulated surplus to the capital account of the corporation; or as was said in Blott's case: "from the reservoir of capital certain proceeds were allowed to flow down the outlet stream, but these proceeds were not allowed to reach the shareholder. The company enlarged the area of the reservoir and put back the proceeds into the enlarged reservoir; in other words, the proceeds in that case never became the profit or gain or income of the shareholder, but were put back into the capital of the company." 44 In Pool's case the outward flow reached the shareholder (a) in cash and (b) in specie of the shares of another company. There was then a complete severance of income from the capital of the company paying the dividend, the recipient receiving it entirely for his own use, benefit, and disposal. As it was put in Eisner v. Macomber, the essential matter is "not a gain accriting to capital, not a growth or increment of value in the investment; but a gain, a profit, something of exchangeable value proceeding from the property, severed from the capital however invested or employed." 45

The differentiation of capital and income reached in these cases is also a differentiation of profit and the earnings of capital. The company is a going concern in which the stockholder has an interest. It was held many years ago that the legal interest of all the stock is in the company, who are trustees for the members. ${ }^{40}$ The modern view is rather that the shareholders each hold a fraction of the totality of ownership of the business clothed with legal form by the corporation. But the essential point is the separation of the business from the shareholders and of the profit of the business from the dividend income of the shareholders. A fraction of ownership is not a fraction of the business, and the shareholder's interest appertains to the entire business. As to the assets, which are a part only of the business, the company is the sole owner, having full title, legal and equitable, to the whole. ${ }^{47}$ When the company makes

43. Id. at 358 .

44. Id. at 359 .

45. 252 U. S. 189, at 207 (1919). (Italicized as cited).

46. Child v. Hudson's Bay Co., 2 P. Wms. 207 (Ch. 1723).

47. Eisner v. Macomber, 252 U. S. 189, 208 (1919). 
profits, these add to the fund which constitutes the business. But unless and until the directors decide to sever part of this fund from the business and divide it amongst the shareholders, passing to them the complete property in each fraction, the shareholder has no certain claim against the going concern for a' share in the assets.

American interpretation of the rule that dividends can be paid only out of profits and must not impair capital has developed strongly this idea that a dividend is a severance of assets. And in -spite of some ap= parent contradictions ${ }^{28}$ the theory contains a coherent conception of profit. It is said that the profit of a corporation is the increase in the net worth of the corporation over a given period, namely the periodic variations to be found in the sum which is computed by adding the capital stock to the surplus. But increases in this "net worth" can be reflected only in variations in the surplus account, since the capital stock is a constant and must necessarily so remain. Therefore, any discussion or determination of the existence of increases in net worth (i.e. profit) must be made in view of changes in surplus. That fund represents the difference between assets and liabilities; the declaration of a dividend reduces it by vesting an addition to the liabilities. However, the mere existence of a surplus does not imply that there is a fund available for immediate dividends. For, the surplus of assets over liabilities represents an increase at the time of ascertainment in the capital of the business in the sense of the fund of assets on which business operation is based, and that increase may not be in a form available for dividend distribution. Unless this capital is sufficient to satisfy all liabilities including the return of the subscriptions to capital stock in case of a dissolution, and in addition leave an excess, then only has a profit been made-because the capital fund has increased. Clearly, there can be no such profit unless the original capital (plus interim additions to it) is intact. And if any of the assets in which the capital is invested are wasting assets or are consumed as revenue is earned, the wastage and consumption must be made good before a profit can appear. ${ }^{40}$

American legal doctrine defines "profit" for the purposes of corporate dividend payments in a manner most nearly approximating the prevailing economic analyses of the concept. It is the one that comes closest to bridging the gap between economics and law in so far as it regards

48. Weiner, Anglo-Anterican Dividend Law (1929) 29 CoL. L Rev. ·461, (1930) 30 Col. L. Rev. 330. See also Rerter, Profits, Drvidendos aitd tre Lay (1926); MAagLL, TATABLE INCONE (1936) Ch. 2, pp. 41-50.

49. Wittenberg v. Federal Mining \& Smeiting Co., 15 Del. Ch. 147, 133 Atl. $4 S$ (Ch. 1936), aff'd, 15 Del. Ch. 409, 138 Atl. 347 (Ch. 1927), (1927) 40 HArs. L. Rev. 318; (1926) 75 U. of PA. L. REv. 89; cf. DE PAULA, op. cit. sispra note 17, at 69. The situation may be different, however, where only stockholders of one class or preference are involved in the controversy. See Iegis. (192S) $2 S$ CoL. L. Rev. 232. 
all the assets of a corporation as its capital-the fund, that is, with which the business is conducted-and determines the existence of profit only by increases in that fund as a whole over its original size whether at the beginning of the accounting period or at the inception of the business. The English doctrine, it appears, has unfortunately, not taken the same course-at least if we are to take the words of the Court of Appeal literally.

Three cases may be cited in conclusion as showing that the truth of the matter was in English law some years ago and that there is probably a much closer correspondence between English and American law than the Court of Appeal would have us believe. In 1882 Lord Shand said: "In order to ascertain the profits earned and divisible at any given time, the balance sheet must contain a fair statement of the liabilities of the company, including its paid up capital, and on the other hand a fair or more properly a bona fide valuation of assets, the balance if in favor of the company being profits." 50 Ten years later Mr. Justice Chitty stated: "T have before me the defendant (banking) company's accounts up to December, 1890. They put down on the one side their liabilities, treating properly the $£ 500,000$, which has been subscribed by the shareholders, as a liability, for the purposes of bringing it into account, as against the assets which they put down on the other side. Then on the same liability side they properly put their current liabilities, and certain other liabilities and reserve fund, which the company, according to its constitution, is justified in making, and they add up the total amount of those liabilities. On the other side they put down their assets, and for the purpose of giving information to the shareholders, they divide the . assets into certain heads ... and then they add up the total on that side . . . They put down on the assets side the money value of their assets, some being in money itself and some not. Then when the two sides of this account are compared, there is a surplus . . . which rightly goes to the profit and loss account." 51 And in 1910 Lord Justice Fletcher Moulton said: "We start . . . with this fundamental definition of profits, namely, if the total assets of the business at the two dates be compared, the increase they show at the later date as compared with the earlier date (due allowance of course being made for any capital introduced into or taken out of the business in the meanwhile) represents in, strictness the profits of the business during the period in question."

.50. City of Glasgow Bank v. Mackinnon, 19 Scor. L. Rev. 278, 316 (1881).

51. Lubbock v. British Bank of South America, [1892] 2 Ch. 198, 200.

52. In re Spanish Prospecting Co., Ltd., [1911] 1 Ch. 92, 99. 